\title{
Emerging functions of RANKL in lymphoid tissues
}

\author{
Christopher G. Mueller ${ }^{1}$ * and Estelle Hess ${ }^{1,2}$ \\ ${ }^{1}$ CNRS, Laboratory of Therapeutic Immunology and Chemistry, Institut de Biologie Moléculaire et Cellulaire, University of Strasbourg, Strasbourg, France \\ 2 Unité de Recherche en Biologie Moléculaire, Facultés Universitaires Notre-Dame de la Paix Namur, Namur, Belgium
}

Edited by:

Burkhard Ludewig, Kantonal Hospital

St. Gallen, Switzerland

\section{Reviewed by:}

Annette Oxenius, Federal Institute of

Technology Zurich, Switzerland

Jorge Caamano, University of

Birmingham, UK

Ifor Williams, Emory University, USA

${ }^{*}$ Correspondence:

Christopher G. Mueller, CNRS,

Laboratory of Therapeutic

Immunology and Chemistry,

UPR9021, Institut de Biologie

Moléculaire et Cellulaire, 15 Rue René

Descartes, University of Strasbourg,

67084 Strasbourg, France.

e-mail: c.mueller@cnrs-ibmc.unistra.fr
The tumor necrosis factor superfamily (TNFSF) members play pivotal roles in embryonic development of lymphoid tissue and their homeostasis. RANKL (Receptor activator of NF$\kappa \mathrm{B}$ ligand, also called TRANCE, TNFSF11) is recognized as an important player in bone homeostasis and lymphoid tissue formation. In its absence bone mass control is deregulated and lymph nodes fail to develop. While its function in bone is well described, there is still little functional insight into the action of RANKL in lymphoid tissue development and homeostasis. Here we provide an overview of the known functions of RANKL, its signaling receptor RANK and its decoy receptor OPG from the perspective of lymphoid tissue development and immune activation in the mouse. Expressed by the hematopoietic lymphoid tissue inducing (LTi) cells and the mesenchymal lymphoid tissue organizer (LTo) cells, RANKL was shown to stimulate Lymphotoxin (LT) expression and to be implicated in LTi cell accumulation. Our recent finding that RANKL also triggers proliferation of adult lymph node stroma suggests that RANKL may furthermore directly activate LTo cells. Beyond bone, the RANKL-RANK-OPG triad plays important roles in immunobiology that are waiting to be unraveled.

Keywords: TRANCE, TNFSF11, OPG, lymphoid organs, lymph node, stroma, LTi, LTo

\section{INTRODUCTION}

Tumor necrosis factor (TNF) and Lymphotoxin (LT) were identified as the first members of a large family, now called the TNFsuperfamily (SF). Not surprisingly, the receptors for these proteins also constitute a SF with sequence homology, named TNF Receptor (TNFR) SF. A hallmark of these ligand-receptor pairs lies in a threefold symmetry, where by the oligomeric binding arrangement amplifies their avidity and introduces flexibility. Further complexity arises through different partner affinities and generation of soluble ligand and receptor forms (Bodmer et al., 2002). RANKL (TNFSF11) is the ligand of two receptors, RANK (TNFRSF11a) and OPG (TNFRSF11b). OPG (osteoprotegerin) was the first of this protein triad to be discovered (Simonet et al., 1997) in a search for an inhibitor of osteoclastogenesis (Tsuda et al., 1997). OPGligand was then isolated and cloned using OPG as bait (Lacey et al., 1998; Yasuda et al., 1998). OPG-ligand turned out to be identical to TRANCE (TNF-related activation induced cytokine), cloned during a search for apoptosis-regulatory genes in $\mathrm{T}$ cells (Wong et al., 1997b), and RANKL (Receptor activator of NF-кB) identified as the ligand for RANK that had attracted attention for its homology to CD40 (Anderson et al., 1997). The affinity of RANKL for OPG is 1000-fold higher than for RANK (Nakagawa et al., 1998), which is dependent on the ability of OPG to homodimerize (Schneeweis et al., 2005). OPG is also a ligand for TNF-related apoptosis-inducing ligand (TRAIL; Emery et al., 1998), however, its affinity for TRAIL is 10,000 times less compared to RANKL (Body et al., 2006) questioning the in vivo relevance of OPGTRAIL interaction. There is now an emerging consensus to refer to the receptor as RANK and, as a consequence and for simplicity, its ligand is called RANKL. The acronym OPG has remained in use.
The discovery of RANK, RANKL, and OPG in bone and the immune system raises the question of its evolutionary origins. The genes arose simultaneously during ontogeny of bony fish as evidenced by gene sequence identification and presence of resorption and remodeling activity of vertebrate mineralized tissue (Witten and Huysseune, 2009). They therefore postdate the formation of the primordial immune system comprising a primitive thymus and lymphoid structures associated with exposed sites. However, they preceded the development of lymph nodes (LNs) and germinal centers arising in amphibians and the emergence of LT $\beta$ receptor, a key molecule in lymphoid development (Glenney and Wiens, 2007; see below). It is therefore likely that the RANK-RANKLOPG protein triad was co-opted by the advanced immune system for higher order structure together with an efficient regulation of immune cell output from the bone marrow before genesis of LT $\beta$ receptor-regulated lymphoid tissues.

RANKL is a type-II transmembrane protein but can also exist in a soluble form by ectodomain shedding and alternative splicing (Ikeda et al., 2001; Hikita et al., 2006; Baud'huin et al., 2007). OPG comprises two C-terminal regions homologous to death domains of TNFR1 or TRAIL receptor, which were found to be functional when OPG was expressed with a transmembrane sequence (Yamaguchi et al., 1998). Natural OPG is unlikely to transmit signals because it misses the transmembrane sequence and is secreted (Simonet et al., 1997). RANK comprises a transmembrane region and a large cytoplasmic domain. Upon interaction with the RANKL trimer RANK undergoes homotrimerization and activates recruitment of TNFR-associated factors (TRAFs; Galibert et al., 1998; Wada et al., 2006). RANK binds five of the six known TRAF-proteins but TRAF6 seems particularly important 
for RANK signaling, because TRAF6 ${ }^{-1-}$ mice present similar phenotypes as Rank ${ }^{-1-}$ mice (Naito et al., 1999). RANK signaling cascades were mostly deciphered in the myeloid lineage and include the canonical and the non-canonical NF- $\mathrm{B}$ pathways (Raju et al., 2011). In mammary glands RANK-activation intersects with proliferative cues through cyclin D1, Id2, and Id4 (Schramek et al., 2011). RANK was recently found to play a role in mammary and in hair follicle epithelial stem cell activation (Schramek et al., 2010; Duheron et al., 2011) and to induce intestinal microfold cells (M cells) differentiation via the Ets transcription factor Spi-B (Kanaya et al., 2012).

\section{RANKL IN BONE AND HEMATOPOIESIS}

A number of reviews have been published on the role of these proteins in regulating bone mass (Suda et al., 1999; Walsh and Choi, 2003; Baud'huin et al., 2007; Leibbrandt and Penninger, 2010). Rankl $^{-1-}$ and Rank ${ }^{-1-}$ mice present osteopetrosis and lack of teeth (Dougall et al., 1999; Kong et al., 1999), whereas Opg ${ }^{-1-}$ animals exhibit osteoporosis (Bucay et al., 1998; Mizuno et al., 1998; Yun et al., 2001). RANK activates the differentiation of bone matrix degrading osteoclasts (OCL) from myeloid precursor cells (Yasuda et al., 1998; Hsu et al., 1999; Figure 1). RANKL and OPG are synthesized by the bone mesenchymal lineage and are under inflammatory and hormonal control (Udagawa et al., 1999; Takeda et al., 2003; Nakashima et al., 2011; Xiong et al., 2011). Another source of RANKL is activated $\mathrm{T}$ cells that can cause abnormal bone resorption by triggering osteoclastogenesis (Takayanagi et al., 2000; Sato et al., 2006).

$\mathrm{T}$ cell lymphopoiesis itself underlies RANK regulation as Rank $^{-1-}$ mice present a block in the progression to $\mathrm{CD}^{-}{ }^{-} \mathrm{CD} 8^{-} \mathrm{CD}_{4}{ }^{-} \mathrm{CD} 25^{-}$thymocytes (Kong et al., 1999). Recently it was shown that also $\mathrm{V} \gamma 5^{+} \mathrm{T}$ cells are under RANK

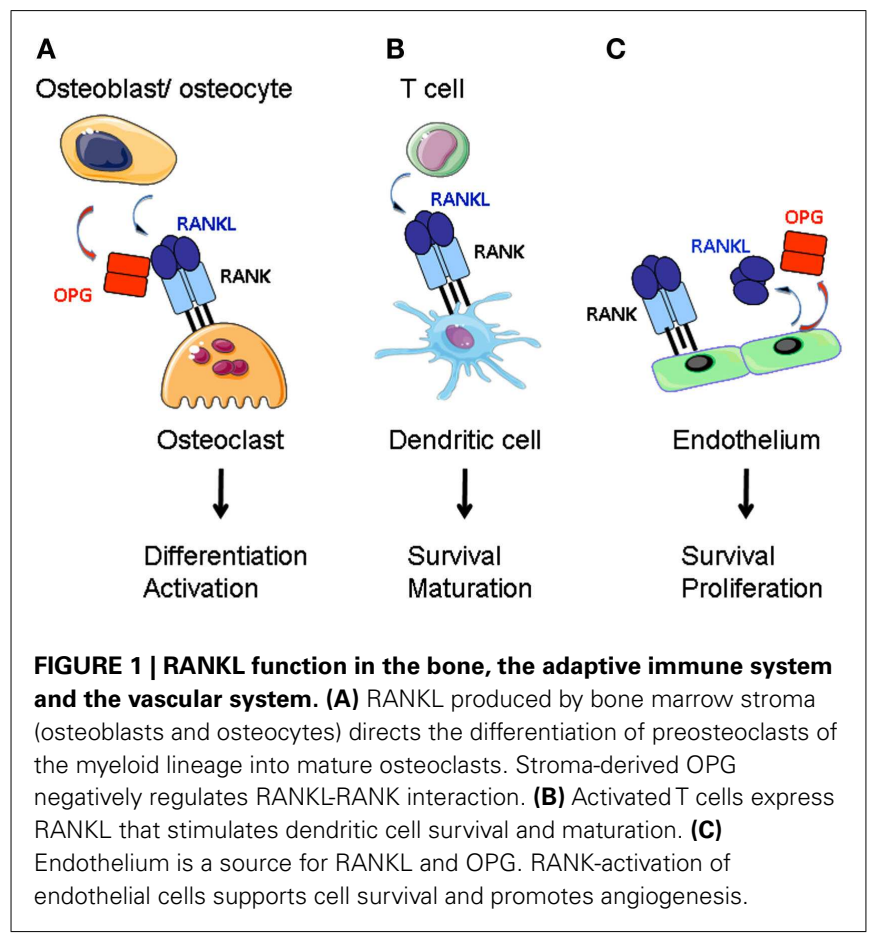

regulatory action (Roberts et al., 2012). In fact RANK signaling is a key event in the early stages of medullary thymic epithelial cell (mTEC) formation, and its cooperation with LT and CD40 signals is required to establish a fully developed medullary microenvironment (Rossi et al., 2007; Akiyama et al., 2008; Hikosaka et al., 2008; Mouri et al., 2011). mTEC play a crucial role in self-tolerance by eliminating self-reactive $\alpha \beta \mathrm{T}$ cells and by regulating the early production of $\gamma \delta \mathrm{T}$ cells. Thymic $\mathrm{CD}^{-}{ }^{-} \mathrm{CD} 4^{+}$lymphoid tissue inducing (LTi) cells and $\mathrm{V} \gamma 5^{+}$thymocytes as well as later arising $\mathrm{CD} 4^{+} \mathrm{CD} 8^{-}$single positive thymocytes and $\gamma \delta \mathrm{T}$ cells are equipped with RANKL (Rossi et al., 2007; Hikosaka et al., 2008; Roberts et al., 2012). RANK and OPG are expressed by mTECs (Hikosaka et al., 2008). Animals defective in RANK signaling also display abnormal B cell hematopoiesis and hypogammaglobulinemia (Dougall et al., 1999; Kong et al., 1999). Although B cells express RANK, in particular in response to activation (Yun et al., 1998; Perlot and Penninger, 2012), a B cell-specific RANK knock-out mouse does not reproduce this phenotype (Perlot and Penninger, 2012), suggesting that the defect lies in bone marrow or splenic stroma.

\section{RANKL IN EARLY STAGES OF SECONDARY LYMPHOID ORGAN DEVELOPMENT}

RANK and RANKL-deficient animals display a complete absence of LNs, defects in Peyer's patches (PPs) and cryptopatches (CPs) and abnormalities of the spleen (Dougall et al., 1999; Kong et al., 1999; Kim et al., 2000; Knoop et al., 2011; Perlot and Penninger, 2012). Therefore the RANK-RANKL-OPG axis shares with the LT and TNF $\alpha$ pathways the control of molecular and cellular processes determinant in secondary lymphoid organ (SLO) development (Tumanov et al., 2003; Fritz and Gommerman, 2010). SLO formation is initiated around embryonic day (E) 15 with the recruitment of the hematopoietic LTi cells to a rudimentary organ anlage composed of mesenchymal and endothelial stroma (White et al., 2007; Vondenhoff et al., 2009; Benezech et al., 2011). The recruitment process is dependent on the chemokine CXCL13 produced by precursors of lymphoid tissue organizer (LTo) cells stimulated by neuronal production of retinoic acid (van de Pavert et al., 2009). This step is followed by a cross-talk between LTi cells that express RANK, RANKL, and LT, and LTo precursors that carry the LT receptor LT $\beta$ R. LT $\beta$ R engagement induces LTo cells to express RANKL and chemokines to attract larger numbers of LTi cells that upon clustering with LTo cells initiate LN organization (Cupedo and Mebius, 2005; Koning and Mebius, 2011; Figure 2).

In view of the finding that LTi cell recruitment is LT independent (Eberl et al., 2004; White et al., 2007; Vondenhoff et al., 2009) the question arises whether LTi cell accumulation is regulated by RANK. Both $\mathrm{Rankl}^{-1-}$ and $\mathrm{Lt \alpha}^{-1-}$ mice have lower number of LTi cells in mesenteric LNs of newborn mice (Kim et al., 2000). TRAF6 $^{-1-}$ mice display fewer LTi cells in mesenteric LNs at E 17.5 but not at E15.5 (Yoshida et al., 2002). Administration of RANKFc antagonist led to a partial reduction in LTi cells, with a more prominent effect in mesenteric LNs (Eberl et al., 2004). Therefore, although current data do not unambiguously support RANKL as a direct regulator of LTi cell numbers, they sustain the concept that RANKL is instrumental for LTi cell accumulation. Of note, 


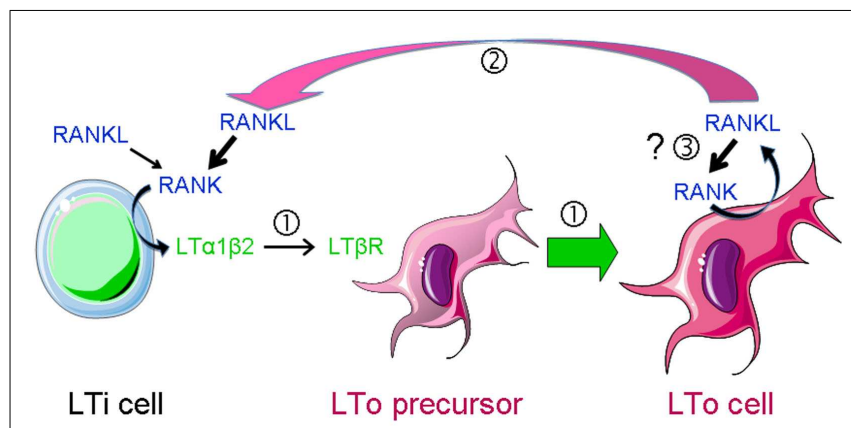

FIGURE 2 | RANKL-dependent amplification loops in SLO development. SLO development during embryogenesis is initiated by the recruitment of lymphoid tissue inducer (LTi) cells to a rudimentary organ anlage composed of mesenchymal lymphoid tissue organizer (LTo) cell progenitors. This step is followed by a cross-talk between LTi cells that express RANKL, RANK, and $L T \alpha \beta$ and LTo cells that carry LT $\beta R$ (1). Engagement of the latter induces the maturation of LTo cells (1) to express RANKL and chemokines that attract larger numbers of LTi cells that upon clustering with LTo cells initiate LN organization. LTo cells also express RANKL. The current model of LN development indicates that a positive feedback loop takes place between LTo and LTi cells via RANKL-RANK and LT $\alpha \beta$-LT $\beta R$ amplifying the early stages of LN development (2). If LTo cells expressed also RANK, a second (autocrine) loop may occur, leading to a direct activation of LTo cells (3).

RANK signaling mediators include Id2 (Kim et al., 2011), a factor indispensable for LTi cell formation (Yokota et al., 1999). It is hence plausible that Id2 is implicated in RANK regulation of LTi cell numbers and function.

In the current model of LN development a positive feedback loop takes place between LTi and LTo cells (Figure 2). RANK signaling in LTi cells increases the expression of LT that upon binding to LT $\beta$ R of LTo cells induces RANKL production, thus amplifying the early stages of LN development (Yoshida et al, 2002; Koning and Mebius, 2011; Roozendaal and Mebius, 2011). In support for such a feedback loop is the observation that RANKL expression is up to 10-fold higher in LTo cells than in LTi cells (Sugiyama et al., 2012). However, it is unlikely that the function of RANKL in SLO development is limited to the induction of LT by LTi cells and the creation of the amplification loop. Firstly, LT is upregulated by a number of other factors, such as IL-7, TNF $\alpha$, and CXCL13 (Ansel et al., 2002). Indeed PPs are LT-dependent but develop in Rankl ${ }^{-1-}$ mice. Second, mucosal LNs develop in LT $\beta^{-1-}$ mice but not in Rankl ${ }^{-1-}$ mice (Alimzhanov et al., 1997; Koni et al., 1997). Finally, administration of an LTßR-agonistic antibody to $\mathrm{Rankl}^{-1-}$ embryos cannot rescue LN genesis (Kim et al., 2000).

LT $\beta R$ signaling in mTECs induces RANK expression (Mouri et al., 2011). We have recently shown that RANK is expressed in adult LN stroma and induces hyperproliferation of reticular fibroblastic and vascular cells (Hess et al., 2012). Expression of both RANK and RANKL by LTo cells may therefore trigger a second (autocrine) loop leading to a direct activation of these cells (Figure 2). In addition, vascular endothelial cells express RANK, RANKL, and OPG that together regulate angiogenesis (Kim et al., 2003; Benslimane-Ahmim et al., 2011; Sugiyama et al., 2012; Figure 1).

\section{RANKL AND SLO GROWTH}

A number of observations support a role of RANKL in SLO growth. The LNs that developed after neutralization of RANK signaling in embryos were smaller (Eberl et al., 2004; Sugiyama et al., 2012). PPs, CPs, and isolated lymphoid follicles (ILFs) were reduced in size in $\mathrm{Rankl}^{-1-}$ mice (Knoop et al., 2011), and postnatal RANKL overproduction led to massive LN hyperplasia (Hess et al., 2012). Recruitment of immune cells and stromal cell division stand out among possible regulatory mechanisms of SLO size. Lymphocyte recruitment into SLO anlage coincides with maturation of LTo cells to produce high levels of chemokines and cell adhesion molecules (Honda et al., 2001; Finke et al., 2002; Luther et al., 2003; Cupedo et al., 2004b; White et al., 2007; Benezech et al., 2011). In mice with postnatal LN hyperplasia RANKL upregulates CXCL13, CCL19, MAdCAM-1, and VCAM-1 gene transcription in adult fibroblastic reticular cells (FRCs) and vascular cells (Hess et al., 2012). Therefore, RANKL could directly boost immune cell accumulation by increased chemokine and adhesion factor output. While recruitment of stromal precursors from surrounding tissue or bone cannot be excluded, CD45-negative cells label for the cell division marker Ki-67 as early as E16 (Eberl et al., 2004; White et al., 2007). Although this proliferation appears to be dependent on LT (White et al., 2007), it is unclear whether the proliferating cells are endothelial cells, precursor or mature LTo cells. We have found that RANKL stimulates FRC and endothelial cell proliferation (Hess et al., 2012). Further support for a functionally important role of RANKL in cell proliferation stems from findings that thymic mTECs and skin keratinocyte cell growth is accelerated in response to RANK stimulation (Hikosaka et al., 2008; Duheron et al., 2011).

\section{TOWARD A ROLE OF RANKL IN B CELL RECRUITIMENT AND FOLLICLE ORGANIZATION}

B cell recruitment and organization into follicles occur in a CXCL13-dependent manner at later stages of SLO formation (Ansel et al., 2000; Cupedo et al., 2004a). B cell follicular dendritic cells (FDCs) and the recently identified marginal reticular cells (MRCs), both mesenchymal cell types, are the main producers of this chemokine (Ansel et al., 2000; Katakai et al., 2008). First supportive evidence for a role of RANKL in B cell recruitment and organization was provided after the rescue of LNs by exogenous IL-7 in TRAF6 ${ }^{-1-}$ mice: it was noted that in these LNs B cells and FDCs were absent (Yoshida et al., 2002). However, because TRAF6 is also a signaling component for TNFR, a critical receptor for FDC formation (Rennert et al., 1998; Endres et al., 1999), a role of RANK signaling in B cell recruitment cannot be directly invoked. More direct evidence was provided by administration of a RANKLneutralizing antibody to embryos. This resulted in reduced LN B cells numbers, misplaced FDCs, and reduced VCAM-1 staining (Sugiyama et al., 2012). In addition, Knoop et al. (2011) noted an absence of B cells in small intestine CPs of Rankl ${ }^{-1-}$ mice and observed that most stromal cells in the B cell compartment lacked VCAM-1 and CXCL13 expression. Finally, postnatal RANKL overexpression resulted in an increase in small but clearly defined B cell follicles, which all comprised FDCs (Hess et al., 2012). Three possible scenarios can be advanced to explain these phenomena: (i) RANKL increases the bone marrow B cell output, (ii) 
CXCL13 production by FDCs and/or MRCs is under RANKL positive control, (iii) RANK-signaling promotes MRC and/or FDC differentiation. Although the first scenario appears plausible in view of the known action of RANKL in the bone, so far, there is no experimental support for this idea. The rise in LN B cell numbers in response to RANKL overproduction is not accompanied by an expansion in splenic transitional B cell subsets (Hess et al., 2012). As for the second model, there is evidence that RANKL upregulates CXCL13 gene transcription in FRCs, however the level of induction was low (Hess et al., 2012). Lastly, reduction of VCAM-1 expression by FDCs is indicative of a requirement of RANK-signaling for terminal differentiation of FDCs. In keeping with this idea, reduced CXCL13 expression by FDCs could be the consequence of FDC dysfunction. It is intriguing that MRCs, which have been proposed to function as FDC precursors, express RANKL (Katakai et al., 2008). Cells that bear resemblance to LN MRCs have also been found in the spleen, PP, and ILF on the grounds of RANKL expression and independence of LT $\beta$ R signaling (Taylor et al., 2007; Katakai et al., 2008). The polarized expression of RANKL beneath the follicle-associated epithelium may be necessary to focus its activity of inducing differentiation of intestinal $\mathrm{M}$ cells, cells specialized in the transport of antigen to the underlying lymphoid tissue (Knoop et al., 2009). It is plausible that RANKL jointly regulates FDC differentiation and (native) antigen access.

\section{RANIKL AND THE ADAPTIVE IMMUNE RESPONSE}

Activated CD4 and CD8 T cells express surface and soluble RANKL (Josien et al., 1999; Wang et al., 2002; Figure 1). Dendritic cells are of the same lineage as OCL and express RANK (Anderson et al., 1997). RANKL confers to DCs better survival with more notable effects on in vitro generated DCs and in combination with other TNFSF members (Wong et al., 1997a; Dougall et al., 1999; Josien et al., 2000; Williamson et al., 2002). Stimulation of DCs results in production of pro-inflammatory cytokines IL6 , IL-1 $\beta$, and $\mathrm{T}$ cell differentiation factors IL-12, IL-15 (Josien et al., 1999). However, other reports have noted anti-inflammatory activity for RANKL. In a model of oral tolerance, RANKL stimulation of DCs has been associated with tolerance induction (Williamson et al., 2002). An anti-inflammatory effect was also noted for RANKL-stimulated Langerhans cells and macrophages (Maruyama et al., 2006; Yoshiki et al., 2009). This discrepancy

\section{REFERENCES}

Akiyama, T., Shimo, Y., Yanai, H., Qin, J., Ohshima, D., Maruyama, Y., Asaumi, Y., Kitazawa, J., Takayanagi, H., Penninger, J. M., Matsumoto, M., Nitta, T., Takahama, Y., and Inoue, J. (2008). The tumor necrosis factor family receptors RANK and CD40 cooperatively establish the thymic medullary microenvironment and self-tolerance. Immunity 29, 423-437.

Alimzhanov, M. B., Kuprash, D. V., Kosco-Vilbois, M. H., Luz, A., Turetskaya, R. L., Tarakhovsky, A., Rajewsky, K., Nedospasov, S. A., and Pfeffer, K. (1997).

may be due to low RANK expression level in immature DCs; its expression being upregulated in response to Toll-like receptor (TLR) ligands or inflammatory cytokines (Hochweller and Anderton, 2005). Another explanation could be a redundancy with other TNFRSF members such as its close homolog CD40 (Bachmann et al., 1999). Alternatively, activated DCs express OPG, thus inhibiting RANKL (Schoppet et al., 2007). Except for a reduction in Langerhans cell numbers (Barbaroux et al., 2008), there is little experimental support that the RANK-RANKL-OPG triad controls DC development in vivo (Dougall et al., 1999).

Th17 T cells represent an important osteoclastogenic $\mathrm{T}$ cell type by robust RANKL production and activation of RANKL release by mesenchymal cells (Sato et al., 2006). This T cell type is of particular importance in progressive periodontitis, a dental disease characterized by destruction of alveolar bone with high prevalence of bacteria such as Porphyromonas gingivalis (Kajiya et al., 2010). In this disease, periodontal ligament fibroblasts are an important source of RANKL when stimulated by microbial products including TLR ligands. TLRs are also expressed by osteoclast precursors and OCL and their stimulation promotes osteoclastogenesis and maturation of OCL. Interestingly, gingival Langerin-expressing DCs have recently been shown to control inflammation in P. gingivalis-induced periodontitis and therefore reduce alveolar bone loss (Arizon et al., 2012). It is yet unclear whether this occurs via a direct RANKL-induced DC anti-inflammatory activity.

\section{CONCLUSION}

The RANK-RANKL-OPG axis plays a recognized role in bone homeostasis through the regulation of osteoclastogenesis. It is also implicated in SLO development and regulation of the immune response. There are many incentives to answer remaining questions. In addition to a restless curiosity of the researcher, tertiary lymphoid tissues that arise in inflamed tissue rely on similar if not identical cellular dialogs as those found in SLO development. Defining RANKL function in lymphoid tissue development will open new therapeutic avenues to treat inflammatory diseases and provide new strategies for vaccine development.

\section{ACKNOWLEDGMENTS}

This work was supported by CNRS, University of Strasbourg, La Ligue contre le Cancer (to Estelle Hess) and the Fondation de Recherche Médicale.

antibody production, and body cavity immunity. Immunity 16 , 67-76.

Ansel, K. M., Ngo, V. N., Hyman, P. L., Luther, S. A., Forster, R., Sedgwick, J. D., Browning, J. L., Lipp, M., and Cyster, J. G. (2000). A chemokinedriven positive feedback loop organizes lymphoid follicles. Nature 406, 309-314.

Arizon, M., Nudel, I., Segev, H., Mizraji, G., Elnekave, M., Furmanov, K., Eli-Berchoer, L., Clausen, B. E., Shapira, L., Wilensky, A., and Hovav, A. H. (2012). Langerhans cells down-regulate inflammationdriven alveolar bone loss. Proc.
Natl. Acad. Sci. U. S. A. 109, 7043-7048.

Bachmann, M. F., Wong, B. R., Josien, R., Steinman, R. M., Oxenius, A., and Choi, Y. (1999). TRANCE, a tumor necrosis factor family member critical for CD40 ligand-independent T helper cell activation. J. Exp. Med. 189, 1025-1031.

Barbaroux, J. B., Beleut, M., Brisken, C., Mueller, C. G., and Groves, R. (2008). Epidermal receptor activator of NF-kB ligand controls langerhans cell numbers and proliferation. J. Immunol. 181, 1103-1108. 
Baud'huin, M., Lamoureux, F., Duplomb, L., Redini, F., and Heymann, D. (2007). RANKL, RANK, osteoprotegerin: key partners of osteoimmunology and vascular diseases. Cell. Mol. Life Sci. 64, 2334-2350.

Benezech, C., White, A., Mader, E., Serre, K., Parnell, S., Pfeffer, K., Ware, C. F., Anderson, G., and Caamano, J. H. (2011). Ontogeny of stromal organizer cells during lymph node development. J. Immunol. 184, 4521-4530.

Benslimane-Ahmim, Z., Heymann, D., Dizier, B., Lokajczyk, A., Brion, R. Laurendeau, I., Bieche, I., Smadja, D. M., Galy-Fauroux, I., ColliecJouault, S., Fischer, A. M., and Boisson-Vidal, C. (2011). Osteoprotegerin, a new actor in vasculogenesis, stimulates endothelial colonyforming cells properties. J. Thromb. Haemost. 9, 834-843.

Bodmer, J. L., Schneider, P., and Tschopp, J. (2002). The molecular architecture of the TNF superfamily. Trends Biochem. Sci. 27, 19-26.

Body, J. J., Facon, T., Coleman, R. E., Lipton, A., Geurs, F., Fan, M., Holloway, D., Peterson, M. C., and Bekker, P. J. (2006). A study of the biological receptor activator of nuclear factor-kappaB ligand inhibitor, denosumab, in patients with multiple myeloma or bone metastases from breast cancer. Clin. Cancer Res. 12, 1221-1228.

Bucay, N., Sarosi, I., Dunstan, C. R., Morony, S., Tarpley, J., Capparelli, C., Scully, S., Tan, H. L., Xu, W., Lacey, D. L., Boyle, W. J., and Simonet, W. S. (1998). osteoprotegerin-deficient mice develop early onset osteoporosis and arterial calcification. Genes Dev. 12, 1260-1268.

Cupedo, T., Lund, F. E., Ngo, V. N., Randall, T. D., Jansen, W., Greuter, M. J., de Waal-Malefyt, R., Kraal, G., Cyster, J. G., and Mebius, R. E. (2004a). Initiation of cellular organization in lymph nodes is regulated by non-B cell-derived signals and is not dependent on CXC chemokine ligand 13. J. Immunol. 173, 4889-4896.

Cupedo, T., Vondenhoff, M. F., Heeregrave, E. J., De Weerd, A. E., Jansen, W., Jackson, D. G., Kraal, G., and Mebius, R. E. (2004b). Presumptive lymph node organizers are differentially represented in developing mesenteric and peripheral nodes. $J$. Immunol. 173, 2968-2975.

Cupedo, T., and Mebius, R. E. (2005). Cellular interactions in lymph node development. J. Immunol. 174, 21-25.
Dougall, W. C., Glaccum, M., Charrier, K., Rohrbach, K., Brasel, K., De Smedt, T., Daro, E., Smith, J., Tometsko, M. E., Maliszewski, C. R., Armstrong, A., Shen, V., Bain, S., Cosman, D., Anderson, D., Morrissey, P. J., Peschon, J. J., and Schuh, J. (1999). RANK is essential for osteoclast and lymph node development. Genes Dev. 13, 2412-2424.

Duheron, V., Hess, E., Duval, M., Decossas, M., Castaneda, B., Klöpper, J. E., Amoasii, L., Barbaroux, J. B., Williams, I. R., Yagita, H., Penninger, J. M., Choi, Y., Lezot, F., Groves, R., Paus, R., and Mueller, C. G. (2011). Receptor Activator of NF-kB (RANK) stimulates the proliferation of epithelial cells of the epidermopilosebaceous unit. Proc. Natl. Acad. Sci. U.S.A. 108, 5342-5347.

Eberl, G., Marmon, S., Sunshine, M. J., Rennert, P. D., Choi, Y., and Littman, D. R. (2004). An essential function for the nuclear receptor RORgamma $(t)$ in the generation of fetal lymphoid tissue inducer cells. Nat. Immunol. 5, 64-73.

Emery, J. G., McDonnell, P., Burke, M. B., Deen, K. C., Lyn, S., Silverman, C., Dul, E., Appelbaum, E. R., Eichman, C., DiPrinzio, R., Dodds, R. A., James, I. E., Rosenberg, M., Lee, J. C., and Young, P. R. (1998). Osteoprotegerin is a receptor for the cytotoxic ligand TRAIL. J. Biol. Chem. 273, 14363-14367.

Endres, R., Alimzhanov, M. B., Plitz, T., Futterer, A., Kosco-Vilbois, M. H., Nedospasov, S. A., Rajewsky, K., and Pfeffer, K. (1999). Mature follicular dendritic cell networks depend on expression of lymphotoxin beta receptor by radioresistant stromal cells and of lymphotoxin beta and tumor necrosis factor by B cells. $J$. Exp. Med. 189, 159-168.

Finke, D., Acha-Orbea, H., Mattis, A., Lipp, M., and Kraehenbuhl, J. (2002). CD4+CD3 - cells induce Peyer's patch development: role of alpha4betal integrin activation by CXCR5. Immunity 17, 363-373.

Fritz, J. H., and Gommerman, J. L. (2010). Cytokine/stromal cell networks and lymphoid tissue environments. J. Interferon Cytokine Res. 6.

Galibert, L., Tometsko, M. E., Anderson, D. M., Cosman, D., and Dougall, W. C. (1998). The involvement of multiple tumor necrosis factor receptor (TNFR)-associated factors in the signaling mechanisms of receptor activator of NF-kappaB, a member of the TNFR superfamily. J. Biol. Chem. 273, 34120-34127.
Glenney, G. W., and Wiens, G. D. (2007). Early diversification of the TNF superfamily in teleosts: genomic characterization and expression analysis. J. Immunol. 178 7955-7973.

Hess, E., Duheron, V., Decossas, M., Lézot, F., Berdal, A., Chea, S., Golub, R., Bosisio, M. R., Bridal, S. L., Choi, Y., Yagita, H., and Mueller, C. G. (2012). RANKL induces organized lymph node growth by stromal cell proliferation. J. Immunol. 188, 1245-1254.

Hikita, A., Yana, I., Wakeyama, H., Nakamura, M., Kadono, Y., Oshima, Y. Nakamura, K., Seiki, M., and Tanaka, S. (2006). Negative regulation of osteoclastogenesis by ectodomain shedding of receptor activator of NF-kappaB ligand. J. Biol. Chem. 281, 36846-36855.

Hikosaka, Y., Nitta, T., Ohigashi, I., Yano, K., Ishimaru, N., Hayashi, Y., Matsumoto, M., Matsuo, K., Penninger, J. M., Takayanagi, H., Yokota, Y., Yamada, H., Yoshikai, Y., Inoue, J., Akiyama, T., and Takahama, Y. (2008). The cytokine RANKL produced by positively selected thymocytes fosters medullary thymic epithelial cells that express autoimmune regulator. Immunity $29,438-450$.

Hochweller, K., and Anderton, S. M. (2005). Kinetics of costimulatory molecule expression by $\mathrm{T}$ cells and dendritic cells during the induction of tolerance versus immunity in vivo. Eur. J. Immunol. 35, 1086-1096.

Honda, K., Nakano, H., Yoshida, H., Nishikawa, S., Rennert, P., Ikuta, K., Tamechika, M., Yamaguchi, K., Fukumoto, T., Chiba, T., and Nishikawa, S. I. (2001). Molecular basis for hematopoietic/mesenchymal interaction during initiation of Peyer's patch organogenesis. J. Exp. Med. 193 621-630.

Hsu, H., Lacey, D. L., Dunstan, C. R., Solovyev, I., Colombero, A., Timms, E., Tan, H. L., Elliott, G., Kelley, M. J., Sarosi, I., Wang, L., Xia, X. Z., Elliott, R., Chiu, L., Black, T., Scully, S., Capparelli, C., Morony, S., Shimamoto, G., Bass, M. B., and Boyle, W. J. (1999). Tumor necrosis factor receptor family member RANK mediates osteoclast differentiation and activation induced by osteoprotegerin ligand. Proc. Natl. Acad. Sci. U.S.A. 96 , 3540-3545.

Ikeda, T., Kasai, M., Utsuyama, M., and Hirokawa, K. (2001). Determination of three isoforms of the receptor activator of nuclear
factor-kappaB ligand and their differential expression in bone and thymus. Endocrinology 142, 1419-1426.

Josien, R., Li, H. L., Ingulli, E., Sarma, S., Wong, B. R., Vologodskaia, M., Steinman, R. M., and Choi, Y. (2000). TRANCE, a tumor necrosis factor family member, enhances the longevity and adjuvant properties of dendritic cells in vivo. J. Exp. Med. 191, 495-502.

Josien, R., Wong, B. R., Li, H. L., Steinman, R. M., and Choi, Y. (1999). TRANCE, a TNF family member, is differentially expressed on $\mathrm{T}$ cell subsets and induces cytokine production in dendritic cells. $J$. Immunol. 162, 2562-2568.

Kajiya, M., Giro, G., Taubman, M. A., Han, X., Mayer, M. P., and Kawai, T. (2010). Role of periodontal pathogenic bacteria in RANKLmediated bone destruction in periodontal disease. J. Oral Microbiol. 2, 5532-5548.

Kanaya, T., Hase, K., Takahashi, D., Fukuda, S., Hoshino, K., Sasaki, I., Hemmi, H., Knoop, K. A., Kumar, N., Sato, M., Katsuno, T., Yokosuka, O., Toyooka, K., Nakai, K., Sakamoto, A., Kitahara, Y., Jinnohara, T., McSorley, S. J., Kaisho, T., Williams, I. R., and Ohno, H. (2012). The Ets transcription factor Spi-B is essential for the differentiation of intestinal microfold cells. Nat. Immunol. 13 , 729-736.

Katakai, T., Suto, H., Sugai, M., Gonda, H., Togawa, A., Suematsu, S., Ebisuno, Y., Katagiri, K., Kinashi, T., and Shimizu, A. (2008). Organizerlike reticular stromal cell layer common to adult secondary lymphoid organs. J. Immunol. 181, 6189-6200.

Kim, D., Mebius, R. E., MacMicking, J. D., Jung, S., Cupedo, T., Castellanos, Y., Rho, J., Wong, B. R., Josien, R., Kim, N., Rennert, P. D., and Choi, Y. (2000). Regulation of peripheral lymph node genesis by the tumor necrosis factor family member TRANCE. J. Exp. Med. 192, 1467-1478.

Kim, H. H., Shin, H. S., Kwak, H. J., Ahn, K. Y., Kim, J. H., Lee, H. J., Lee, M. S., Lee, Z. H., and Koh, G. Y. (2003). RANKL regulates endothelial cell survival through the phosphatidylinositol $3^{\prime}$-kinase/Akt signal transduction pathway. FASEB J. 17, 2163-2165.

Kim, N. S., Kim, H. T., Kwon, M. C., Choi, S. W., Kim, Y. Y., Yoon, K. J., Koo, B. K., Kong, M. P., Shin, J., Cho, Y., and Kong, Y. Y. (2011). Survival and differentiation of mammary epithelial cells in mammary gland development require nuclear 
retention of Id2 due to RANK signaling. Mol. Cell. Biol. 31, 4775-4788.

Knoop, K. A., Butler, B. R., Kumar, N., Newberry, R. D., and Williams, I. R. (2011). Distinct developmental requirements for isolated lymphoid follicle formation in the small and large intestine RANKL is essential only in the small intestine. Am. J. Pathol. 179, 1861-1871.

Knoop, K. A., Kumar, N., Butler, B. R., Sakthivel, S. K., Taylor, R. T., Nochi, T., Akiba, H., Yagita, H., Kiyono, H., and Williams, I. R. (2009). RANKL is necessary and sufficient to initiate development of antigen-sampling $\mathrm{M}$ cells in the intestinal epithelium. $J$. Immunol. 183, 5738-5747.

Kong, Y. Y., Yoshida, H., Sarosi, I., Tan, H. L., Timms, E., Capparelli, C., Morony, S., Oliveira-dos-Santos, A. J., Van, G., Itie, A., Khoo, W., Wakeham, A., Dunstan, C. R., Lacey, D. L., Mak, T. W., Boyle, W. J., and Penninger, J. M. (1999). OPGL is a key regulator of osteoclastogenesis, lymphocyte development and lymph-node organogenesis. Nature 397, 315-323.

Koni, P. A., Sacca, R., Lawton, P., Browning, J. L., Ruddle, N. H., and Flavell, R. A. (1997). Distinct roles in lymphoid organogenesis for lymphotoxins alpha and beta revealed in lymphotoxin beta-deficient mice. Immunity 6, 491-500.

Koning, J. J., and Mebius, R. E. (2011). Interdependence of stromal and immune cells for lymph node function. Trends Immunol. 33, 264-270.

Lacey, D. L., Timms, E., Tan, H. L., Kelley, M. J., Dunstan, C. R., Burgess, T., Elliott, R., Colombero, A., Elliott, G., Scully, S., Hsu, H., Sullivan, J., Hawkins, N., Davy, E., Capparelli, C., Eli, A., Qian, Y. X., Kaufman, S., Sarosi, I., Shalhoub, V., Senaldi, G., Guo, J., Delaney, J., and Boyle, W. J. (1998). Osteoprotegerin ligand is a cytokine that regulates osteoclast differentiation and activation. Cell 93, 165-176.

Leibbrandt, A., and Penninger, J. M. (2010). Novel Functions of RANK(L) Signaling in the Immune System. Adv. Exp. Med. Biol. 658, 77-94.

Luther, S. A., Ansel, K. M., and Cyster, J. G. (2003). Overlapping roles of CXCL13, interleukin 7 receptor alpha, and CCR7 ligands in lymph node development. J. Exp. Med. 197, 1191-1198.

Maruyama, K., Takada, Y., Ray, N., Kishimoto, Y., Penninger, J. M., Yasuda, H., and Matsuo, K. (2006). Receptor activator of NF-kappa B ligand and osteoprotegerin regulate proinflammatory cytokine production in mice. J. Immunol. 177, 3799-3805.

Mizuno, A., Amizuka, N., Irie, K., Murakami, A., Fujise, N., Kanno, T., Sato, Y., Nakagawa, N., Yasuda, H., Mochizuki, S., Gomibuchi, T., Yano, K., Shima, N., Washida, N., Tsuda, E., Morinaga, T., Higashio, K., and Ozawa, H. (1998). Severe osteoporosis in mice lacking osteoclastogenesis inhibitory factor/osteoprotegerin. Biochem. Biophys. Res. Commun. 247, 610-615.

Mouri, Y., Yano, M., Shinzawa, M., Shimo, Y., Hirota, F., Nishikawa, Y., Nii, T., Kiyonari, H., Abe, T., Uehara, H., Izumi, K., Tamada, K., Chen, L., Penninger, J. M., Inoue, J. I., Akiyama, T., and Matsumoto, M. (2011). Lymphotoxin signal promotes thymic organogenesis by eliciting RANK expression in the embryonic thymic stroma. $J$. Immunol. 186, 5047-5057.

Naito, A., Azuma, S., Tanaka, S., Miyazaki, T., Takaki, S., Takatsu, K., Nakao, K., Nakamura, K., Katsuki, M., Yamamoto, T., and Inoue, J. (1999). Severe osteopetrosis, defective interleukin-1 signalling and lymph node organogenesis in TRAF6-deficient mice. Genes Cells 4, 353-362.

Nakagawa, N., Kinosaki, M., Yamaguchi, K., Shima, N., Yasuda, H., Yano, K., Morinaga, T., and Higashio, K. (1998). RANK is the essential signaling receptor for osteoclast differentiation factor in osteoclastogenesis. Biochem. Biophys. Res. Commun. 253, 395-400.

Nakashima, T., Hayashi, M., Fukunaga, T., Kurata, K., Oh-Hora, M., Feng, J. Q., Bonewald, L. F., Kodama, T., Wutz, A., Wagner, E. F., Penninger, J. M., and Takayanagi, $\mathrm{H}$. (2011). Evidence for osteocyte regulation of bone homeostasis through RANKL expression. Nat. Med. 17, 1231-1234.

Perlot, T., and Penninger, J. M. (2012). Development and function of murine B cells lacking RANK. J. Immunol. 188, 1201-1205.

Raju, R., Balakrishnan, L., Nanjappa, V., Bhattacharjee, M., Getnet, D., Muthusamy, B., Kurian Thomas, J., Sharma, J., Rahiman, B. A., Harsha, H. C., Shankar, S., Prasad, T. S., Mohan, S. S., Bader, G. D., Wani, M. R., and Pandey, A. (2011). A comprehensive manually curated reaction map of RANKL/RANKsignaling pathway. Database 2011. doi: 10.1093/database/bar021

Rennert, P. D., James, D., MacKay, F., Browning, J. L., and Hochman, P.
S. (1998). Lymph node genesis is induced by signaling through the lymphotoxin beta receptor. Immunity 9, 71-79.

Roberts, N. A., White, A. J., Jenkinson, W. E., Turchinovich, G., Nakamura, K., Withers, D. R., McConnell, F. M., Desanti, G. E., Benezech, C., Parnell, S. M., Cunningham, A. F., Paolino, M., Penninger, J. M., Simon, A. K., Nitta, T., Ohigashi, I., Takahama, Y., Caamano, J. H., Hayday, A. C., Lane, P. J., Jenkinson, E. J., and Anderson, G. (2012). Rank signaling links the development of invariant gammadelta $\mathrm{T}$ cell progenitors and aire(+) medullary epithelium. Immunity 36, 427-437.

Roozendaal, R., and Mebius, R. E. (2011). Stromal cell-immune cell interactions. Annu. Rev. Immunol. 29, 23-43.

Rossi, S. W., Kim, M. Y., Leibbrandt, A., Parnell, S. M., Jenkinson, W. E., Glanville, S. H., McConnell, F. M., Scott, H. S., Penninger, J. M., Jenkinson, E. J., Lane, P. J., and Anderson, G. (2007). RANK signals from $\mathrm{CD} 4+3$ - inducer cells regulate development of Aireexpressing epithelial cells in the thymic medulla. J. Exp. Med. 14, 14.

Sato, K., Suematsu, A., Okamoto, K., Yamaguchi, A., Morishita, Y., Kadono, Y., Tanaka, S., Kodama, T., Akira, S., Iwakura, Y., Cua, D. J., and Takayanagi, H. (2006). Th17 functions as an osteoclastogenic helper $\mathrm{T}$ cell subset that links $\mathrm{T}$ cell activation and bone destruction. $J$. Exp. Med. 203, 2673-2682.

Schneeweis, L. A., Willard, D., and Milla, M. E. (2005). Functional dissection of osteoprotegerin and its interaction with receptor activator of NFkappaB ligand. J. Biol. Chem. 280, 41155-41164.

Schoppet, M., Henser, S., Ruppert, V., Stubig, T., Al-Fakhri, N., Maisch, B., and Hofbauer, L. C. (2007). Osteoprotegerin expression in dendritic cells increases with maturation and is NF-kappaB-dependent. J. Cell. Biochem. 100, 1430-1439.

Schramek, D., Leibbrandt, A., Sigl, V., Kenner, L., Pospisilik, J. A., Lee, H. J., Hanada, R., Joshi, P. A., Aliprantis, A., Glimcher, L., Pasparakis, M., Khokha, R., Ormandy, C. J., Widschwendter, M., Schett, G., and Penninger, J. M. (2010). Osteoclast differentiation factor RANKL controls development of progestindriven mammary cancer. Nature $468,98-102$.

Schramek, D., Sigl, V., and Penninger, J. M. (2011). RANKL and RANK in sex hormone-induced breast cancer and breast cancer metastasis. Trends Endocrinol. Metab. 22, 188-194.

Simonet, W. S., Lacey, D. L., Dunstan, C. R., Kelley, M., Chang, M. S., Luthy, R., Nguyen, H. Q., Wooden, S., Bennett, L., Boone, T., Shimamoto, G., DeRose, M., Elliott, R., Colombero, A., Tan, H. L., Trail, G., Sullivan, J., Davy, E., Bucay, N., Renshaw-Gegg, L., Hughes, T. M., Hill, D., Pattison, W., Campbell, P., Sander, S., Van, G., Tarpley, J., Derby, P., Lee, R., and Boyle, W. J. (1997). Osteoprotegerin: a novel secreted protein involved in the regulation of bone density. Cell 89, 309-319.

Suda, T., Takahashi, N., Udagawa, N., Jimi, E., Gillespie, M. T., and Martin, T. J. (1999). Modulation of osteoclast differentiation and function by the new members of the tumor necrosis factor receptor and ligand families. Endocr. Rev. 20, 345-357.

Sugiyama, M., Nakato, G., Jinnohara, T., Akiba, H., Okumura, K., Ohno, H., and Yoshida, H. (2012). Expression pattern changes and function of RANKL during mouse lymph node microarchitecture development. Int. Immunol. 2012, 21.

Takayanagi, H., Ogasawara, K., Hida, S., Chiba, T., Murata, S., Sato, K., Takaoka, A., Yokochi, T., Oda, H., Tanaka, K., Nakamura, K., and Taniguchi, T. (2000). T-cellmediated regulation of osteoclastogenesis by signalling cross-talk between RANKL and IFN-gamma. Nature 408, 600-605.

Takeda, S., Elefteriou, F., and Karsenty, G. (2003). Common endocrine control of body weight, reproduction, and bone mass. Annu. Rev. Nutr. 23 , 403-411.

Taylor, R. T., Patel, S. R., Lin, E., Butler, B. R., Lake, J. G., Newberry, R. D., and Williams, I. R. (2007). Lymphotoxin-independent expression of TNF-related activationinduced cytokine by stromal cells in cryptopatches, isolated lymphoid follicles, and Peyer's patches. $J$. Immunol. 178, 5659-5667.

Tsuda, E., Goto, M., Mochizuki, S., Yano, K., Kobayashi, F., Morinaga, T., and Higashio, K. (1997). Isolation of a novel cytokine from human fibroblasts that specifically inhibits osteoclastogenesis. Biochem. Biophys. Res. Commun. 234, 137-142.

Tumanov, A. V., Kuprash, D. V., and Nedospasov, S. A. (2003). The role of lymphotoxin in development and maintenance of secondary lymphoid tissues. Cytokine Growth Factor Rev. 14, 275-288.

Udagawa, N., Takahashi, N., Jimi, E., Matsuzaki, K., Tsurukai, T., Itoh, 
K., Nakagawa, N., Yasuda, H., Goto, M., Tsuda, E., Higashio, K., Gillespie, M. T., Martin, T. J., and Suda, T. (1999). Osteoblasts/stromal cells stimulate osteoclast activation through expression of osteoclast differentiation factor/RANKL but not macrophage colony-stimulating factor: receptor activator of NF-kappa B ligand. Bone 25, 517-523.

van de Pavert, S. A., Olivier, B. J., Goverse, G., Vondenhoff, M. F., Greuter, M., Beke, P., Kusser, K., Hopken, U. E., Lipp, M., Niederreither, K., Blomhoff, R., Sitnik, K., Agace, W. W., Randall, T. D., de Jonge, W. J., and Mebius, R. E. (2009). Chemokine CXCL13 is essential for lymph node initiation and is induced by retinoic acid and neuronal stimulation. Nat. Immunol. 10, 1193-1199.

Vondenhoff, M. F., Greuter, M., Goverse, G., Elewaut, D., Dewint, P., Ware, C. F., Hoorweg, K., Kraal, G., and Mebius, R. E. (2009). LTbetaR signaling induces cytokine expression and up-regulates lymphangiogenic factors in lymph node anlagen. $J$. Immunol. 182, 5439-5445.

Wada, T., Nakashima, T., Hiroshi, N., and Penninger, J. M. (2006). RANKL-RANK signaling in osteoclastogenesis and bone disease. Trends. Mol. Med. 12, 17-25.

Walsh, M. C., and Choi, Y. (2003). Biology of the TRANCE axis. Cytokine Growth Factor Rev. 14, 251-263.

Wang, R., Zhang, L., Zhang, X., Moreno, J., Celluzzi, C., Tondravi, M., and Shi, Y. (2002). Regulation of activationinduced receptor activator of NFkappaB ligand (RANKL) expression in $\mathrm{T}$ cells. Eur. J. Immunol. 32, 1090-1098.
White, A., Carragher, D., Parnell, S., Msaki, A., Perkins, N., Lane, P., Jenkinson, E., Anderson, G., and Caamano, J. H. (2007). Lymphotoxin a-dependent and -independent signals regulate stromal organizer cell homeostasis during lymph node organogenesis. Blood 110, 1950-1959.

Williamson, E., Bilsborough, J. M., and Viney, J. L. (2002). Regulation of Mucosal Dendritic Cell Function by Receptor Activator of NF-kappaB (RANK)/RANK Ligand Interactions: Impact on Tolerance Induction. J. Immunol. 169, 3606-3612.

Witten, P. E., and Huysseune, A. (2009). A comparative view on mechanisms and functions of skeletal remodelling in teleost fish, with special emphasis on osteoclasts and their function. Biol. Rev. 84, 315-346.

Wong, B. R., Josien, R., Lee, S. Y., Sauter, B., Li, H. L., Steinman, R. M., and Choi, Y. (1997a). TRANCE (tumor necrosis factor [TNF]-related activation-induced cytokine), a new TNF family member predominantly expressed in $\mathrm{T}$ cells, is a dendritic cell-specific survival factor. J. Exp. Med. 186, 2075-2080.

Wong, B. R., Rho, J., Arron, J., Robinson, E., Orlinick, J., Chao, M., Kalachikov, S., Cayani, E., Bartlett, F. S. III, Frankel, W. N., Lee, S. Y., and Choi, Y. (1997b). TRANCE is a novel ligand of the tumor necrosis factor receptor family that activates c-Jun $\mathrm{N}$-terminal kinase in T cells. J. Biol. Chem. 272, 25190-25194.

Xiong, J., Onal, M., Jilka, R. L., Weinstein, R. S., Manolagas, S. C., and O'Brien, C. A. (2011). Matrix-embedded cells control osteoclast formation. Nat. Med. 17, 1235-1241.

Yamaguchi, K., Kinosaki, M., Goto, M., Kobayashi, F., Tsuda, E., Morinaga, T., and Higashio, K. (1998). Characterization of structural domains of human osteoclastogenesis inhibitory factor. J. Biol. Chem 273, 5117-5123.

Yasuda, H., Shima, N., Nakagawa, N., Yamaguchi, K., Kinosaki, M., Mochizuki, S., Tomoyasu, A., Yano K., Goto, M., Murakami, A., Tsuda, E., Morinaga, T., Higashio, K. Udagawa, N., Takahashi, N., and Suda, T. (1998). Osteoclast differentiation factor is a ligand for osteoprotegerin/osteoclastogenesisinhibitory factor and is identical to TRANCE/RANKL. Proc. Natl. Acad. Sci. U.S.A. 95, 3597-3602.

Yokota, Y., Mansouri, A., Mori, S., Sugawara, S., Adachi, S., Nishikawa S., and Gruss, P. (1999). Development of peripheral lymphoid organs and natural killer cells depends on the helix-loop-helix inhibitor Id2. Nature 397, 702-706.

Yoshida, H., Naito, A., Inoue, J., Satoh, M., Santee-Cooper, S. M., Ware, C. F., Togawa, A., and Nishikawa, S. (2002). Different cytokines induce surface lymphotoxin-alphabeta on IL-7 receptor-alpha cells that differentially engender lymph nodes and Peyer's patches. Immunity 17, 823-833.

Yoshiki, R., Kabashima, K., Sugita, K. Atarashi, K., Shimauchi, T., and Tokura, Y. (2009). IL-10-producing Langerhans cells and regulatory $\mathrm{T}$ cells are responsible for depressed contact hypersensitivity in grafted skin. J. Invest. Dermatol. 129 705-713.
Yun, T. J., Chaudhary, P. M., Shu, G. L., Frazer, J. K., Ewings, M. K., Schwartz, S. M., Pascual, V., Hood, L. E., and Clark, E. A. (1998). OPG/FDCR-1, a TNF receptor family member, is expressed in lymphoid cells and is up-regulated by ligating CD40. J. Immunol. 161, 6113-6121.

Yun, T. J., Tallquist, M. D., Aicher, A., Rafferty, K. L., Marshall, A. J., Moon, J. J., Ewings, M. E., Mohaupt, M., Herring, S. W., and Clark, E. A. (2001). Osteoprotegerin, a crucial regulator of bone metabolism, also regulates B cell development and function. J. Immunol. 166, 1482-1491.

Conflict of Interest Statement: The authors declare that the research was conducted in the absence of any commercial or financial relationships that could be construed as a potential conflict of interest.

Received: 20 June 2012; paper pending published: 13 July 2012; accepted: 01 August 2012; published online: 03 September 2012.

Citation: Mueller CG and Hess E (2012) Emerging functions of RANKL in lymphoid tissues. Front. Immun. 3:261. doi: 10.3389/fimmu.2012.00261

This article was submitted to Frontiers in Antigen Presenting Cell Biology, a specialty of Frontiers in Immunology. Copyright (C) 2012 Mueller and Hess. This is an open-access article distributed under the terms of the Creative Commons Attribution License, which permits use, distribution and reproduction in other forums, provided the original authors and source are credited and subject to any copyright notices concerning any third-party graphics etc. 